\title{
First treatment of Crohn's disease refractory anastomotic stricture with a lumen-apposing metallic stent suitable for colonoscopy
}

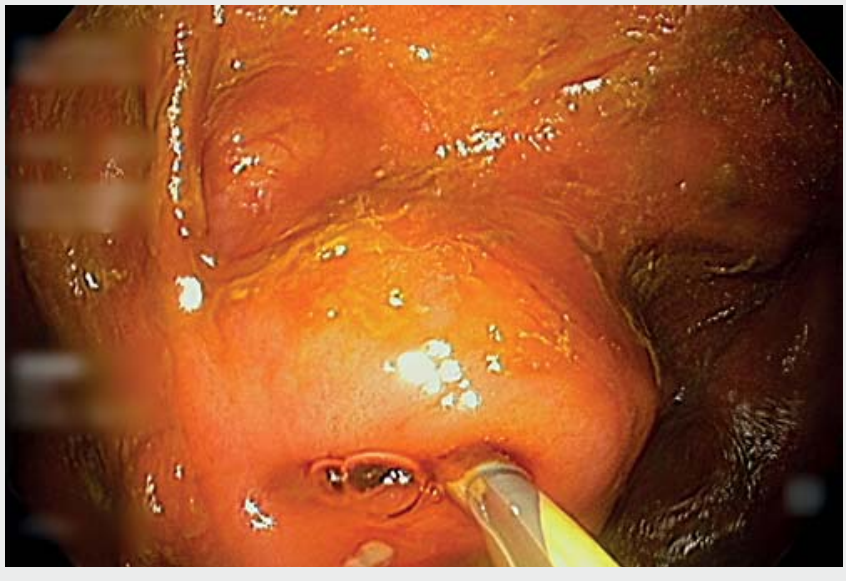

Video 1 Stenting of an anastomotic Crohn's stricture.

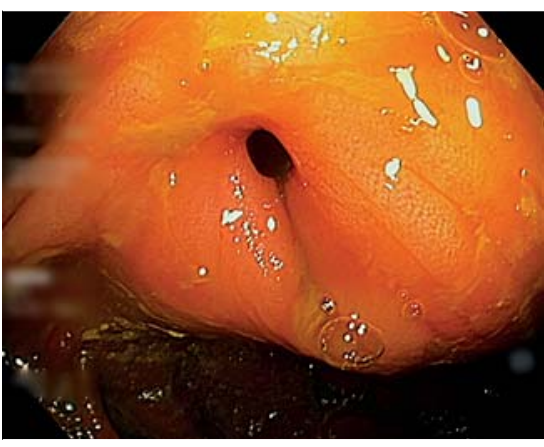

- Fig. 1 lleocolonic anastomotic stricture.

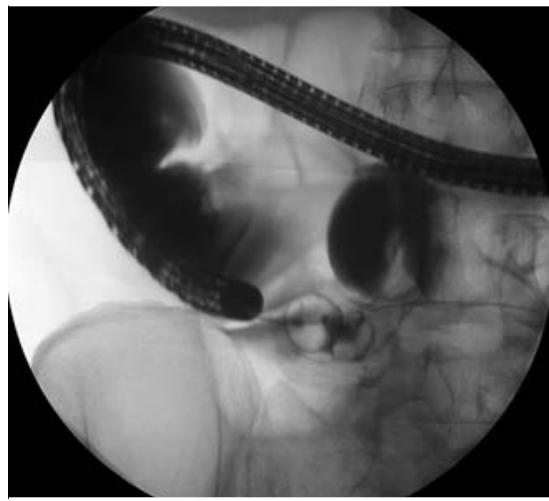

- Fig. 2 Balloon probe set beyond the stricture confirming the short nature of the stricture.

LAMS in Crohn's strictures [3-5], widespread use has not followed, partly because the short delivery catheter of the currently used model (AXIOS; Boston Scientific, Marlborough, Massachusetts, USA) is only compatible with gastroscopes.

The Niti-S-SPAXUS stent has a 180-cm delivery system that is compatible with colonoscopes, making it particularly suitable for benign refractory strictures remotely located in the colon, such as anastomotic Crohn's strictures.

To our knowledge, this is the first use of this stent in this indication. Being able to use LAMS during colonic examination might ease and increase the use of this effective treatment.

Endoscopy_UCTN_Code_TTT_1AQ_2A]

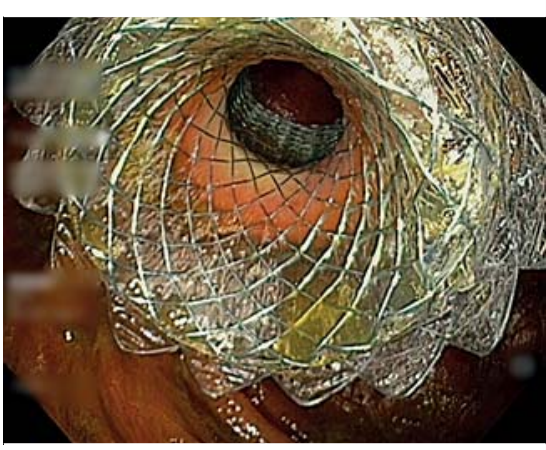

- Fig. 3 SPAXUS stent (Taewoong Medical, Gyeonggi-do, South Korea) set in the ileocolic anastomotic stricture. The whitening of the mucosa reflects the dilation of the stricture by the prosthesis. 


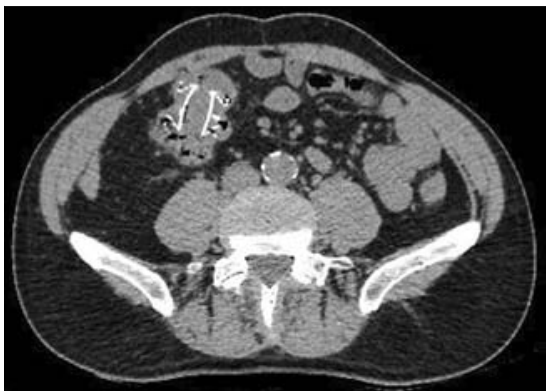

- Fig. 4 A week after the procedure, a computed tomography scan was performed to investigate rectal bleeding (which happened to be proctologic) and confirmed the correct position of the SPAXUS stent.

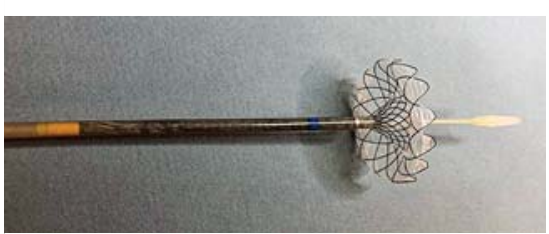

- Fig. 5 Half-opened SPAXUS stent (Taewoong Medical, Gyeonggi-do, South Korea).

\section{Competing interests}

The authors declare that they have no conflict of interest.
The authors

Gabriel Marcellier ${ }^{1} \stackrel{\odot}{ }$, Diane Lorenzo ${ }^{1}$, Abdellah Hedjoudje ${ }^{1}$, Benedicte Jais ${ }^{1}$, Yoram Bouhnik $^{2}$, Frederic Prat ${ }^{1}$

1 Endoscopy Unit, Beaujon Hospital, Clichy, France

2 Gastroenterology and Nutrition Support Department, Department of Gastroenterology, Beaujon Hospital, Clichy, France

\section{Corresponding author}

\section{Gabriel Marcellier, MD}

Endoscopy Unit, Beaujon Hospital, 100 Boulevard du Général Leclerc, 92110 Clichy, France

gabriel.marcellier@aphp.fr

\section{References}

[1] Attar A, Branche J, Coron E et al. An antimigration self-expandable and removable metal stent for Crohn's disease strictures: a nationwide study from the GETAID and the SFED. J Crohns Colitis 2021; 15: 521-528

[2] Shen B, Kochhar G, Navaneethan U et al. Practical guidelines on endoscopic treatment for Crohn's disease strictures: a consensus statement from the Global Interventional Inflammatory Bowel Disease Group. Lancet Gastroenterol Hepatol 2020; 5: 393405

[3] Jain D, Patel U, Ali S et al. Efficacy and safety of lumen-apposing metal stent for benign gastrointestinal stricture. Ann Gastroenterol 2018; 31: 425-438
[4] Majumder S, Buttar N, Gostout C et al. Lumen-apposing covered self-expanding metal stent for management of benign gastrointestinal strictures. Endosc Int Open 2015; 04: 96-101

[5] Axelrad J, Lichtiger S, Sethi A et al. Treatment of Crohn's disease anastomotic stricture with a lumen-apposing metal stent. Clin Gastroenterol Hepatol 2018; 16: 25-26

\section{Bibliography}

Endoscopy 2022; 54: E409-E410

DOI 10.1055/a-1559-1279

ISSN 0013-726X

published online 8.9.2021

(c) 2021. Thieme. All rights reserved.

Georg Thieme Verlag KG, Rüdigerstraße 14,

70469 Stuttgart, Germany

\section{ENDOSCOPY E-VIDEOS \\ https://eref.thieme.de/e-videos}

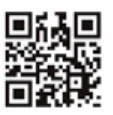

Endoscopy E-Videos is an open access online section, reporting on interesting cases and new techniques in gastroenterological endoscopy. All papers include a high quality video and all contributions are freely accessible online. Processing charges apply (currently EUR 375), discounts and wavers acc. to HINARI are available.

This section has its own submission website at

https://mc.manuscriptcentral.com/e-videos 